\title{
Voters AS A Hard Budget Constraint: On the Determination of Intergovernmental Grants
}

\author{
LARS P. FELD ${ }^{1,2,3, *}$ and CHRISTOPH A. SCHALTEGGER ${ }^{2,4,5}$ \\ ${ }^{1}$ Public Finance Group, Phillips University of Marburg, Am Plan 2, D-35037, Marburg, Germany; \\ ${ }^{2}$ University of St. Gallen, Switzerland; ${ }^{3}$ CESifo, Munich; ${ }^{4}$ Swiss Federal Tax Administration (FTA), \\ Switzerland; ${ }^{5}$ University of Basel, Switzerland; *Author for correspondence: \\ E-mailfeld@wiwi.uni-marburg.de
}

Accepted 24 January, 2004

Abstract. Recent empirical literature has shown that the determination of intergovernmental grants is highly influenced by the political bargaining power of the recipient states. In these models federal politicians are assumed to buy the support of state voters, state politicians and state interest groups by providing grants. In this paper we provide evidence that the fiscal referendum reduces the reliance of states on matching grants received from the central government and thus the possibility of interest groups and state bureaucrats to obtain more grants. If referendums are available, voters serve as a hard budget constraint.

\section{Introduction}

Although equalizing grants are not a necessary feature of fiscal federalism, they definitely play an important quantitative role in most federalist countries and are often justified by some social values. Traditionally, the economic discussion on the distribution of intergovernmental grants focuses on efficiency and equity reasons (Gramlich, 1977; Oates, 1999). It is widely recognized that such grants should be targeted to mitigate externalities in federalist countries. Such interjurisdictional externalities might result because citizens in one jurisdiction, e.g., the suburbs, enjoy the benefits of public services in the other jurisdiction, e.g., the central city, without contributing an adequate tax price (see for example theaters in central cities). Or cost spillovers occur because a jurisdiction is exporting taxes to citizens from other jurisdictions (for example corporate income taxes on foreign owned firms). Finally, fiscal externalities might result from tax competition between jurisdictions causing fiscally induced migration of production factors into a jurisdiction, which reduces the tax burden of factors already established there, and increases the burden of factors remaining in the original jurisdiction. An appropriately designed system of intergovernmental grants is perceived as an efficient instrument for internalizing such interjurisdictional externalities. In addition, fiscal equalization across jurisdictions is also targeted to improve the fiscal capacity of the needy regions. 
Grants are either organized as conditional or as lump-sum transfers. Conditional grants are available when certain restrictions are met by the recipient governments, whereas lump-sum grants are unconditional and may be used according to the wishes of the recipients. Conditional grants often take the form of matching grants: A certain amount of a specified project is financed by the donating government, but has to be supplemented by expenditure of the recipient government. This is done in order to induce the recipient government to take the spillovers of the project into proper consideration when taking its decisions. Thus, the matching share should reflect the size of the spillover effect. Contrarily, lump-sum transfers often serve for equalizing fiscal capacity between jurisdictions.

In contrast to these normative considerations, little attention has been paid to the positive aspects of grants. There is hardly any exception to this verdict, but one figures prominently in the literature: Over the last 30 years, many studies report that intergovernmental grants to state and local governments increase their public expenditure more than an equal increase in private income (Gramlich, 1977). This phenomenon is known as the flypaper effect. Money in the public sector, stemming from intergovernmental grants, tends to remain in the public sector and to get spent there: "money sticks where it hits" (Hines and Thaler, 1995). Using data from Michigan school districts, Wyckhoff (1991) rejects the argument that the cause of the flypaper effect lies in some econometric misspecification or in voters' confusion about the marginal costs of public goods. He suggests that the flypaper effect is rather caused by the decision-making process of recipient governments than by the lack of voters' knowledge.

Others therefore study the decision-making processes shaping decisions about and the demand for intergovernmental grants. An important step in the analysis has been the consideration of integrating the impact of state interest groups in order to explain the distribution of intergovernmental grants. Grossman (1994) formulates and tests a model in which grants are assumed to buy the support of state voters, state politicians and state interest groups. He provides empirical evidence that the stronger the power of state bureaucrats and state interest groups, the higher the amount of grants the state receives. Research on the impact of legislators on the determination of intergovernmental grants has also been advanced in many ways. In an empirical study on the patterns of New Deal spending between 1933 and 1939 in the United States Anderson and Tollison (1991) show that tenure of senators and representatives in decisive committees is positively correlated with the amount of federal funds they can assign to their states. Tovmo and Falch (2002) provide evidence that the flypaper-effect is the result of weak political leadership in fragmented councils using data of Norwegian local governments during the 1930s. In studies on the German fiscal equalization system, Pitlik, Schmid and Strotmann (2001) and Schneider, Pitlik and Strotmann (2001) argue that 
smaller states have a higher bargaining power in the determination of intergovernmental grants in the second chamber of parliament (the "Bundesrat") due to a lower shadow price of their votes. As the federal government depends on the majority of the second chamber there is an incentive to buy the votes of smaller states. None of these studies has however analyzed which constitutional differences matter for the size of intergovernmental grants. In particular, no empirical evidence exists about the importance of grants in direct and representative democracy.

In this paper, we present first evidence on the impact of direct democracy on the size of intergovernmental grants in Switzerland using yearly panel data of Swiss cantons from 1980 to 1998. In addition, we investigate whether union density and the share of farmers from total employment at the cantonal level, as proxies for the size of cantonal interest groups, and the share of employees in cantonal administrations as a proxy for the power of the cantonal bureaucracy, have an impact on the grant system. We finally argue that in jurisdictions where the impact of state voters on the budgetary decision-making process is strong, the state budget relies to a significantly lesser extent on grants received from the central government. If fiscal referendums are available voters serve as a hard budget constraint.

The remainder of the paper is organized as follows: In the next section, we develop theoretical hypotheses as to what impact fiscal referendums have on grants by discussing the potential interaction between voters and state officials on the one hand and between voters and interest groups on the other hand. Under the section Intergovernmental Grants and Institutional Variation the Swiss system of intergovernmental grants and the cantonal differences in institutions of direct democracy are briefly described and introduced. The econometric model is presented in the Empirical Model followed by the Discussion section. We conclude in the Conclusions section.

\section{Intergovernmental Grants and Direct Democracy}

Direct democracy may affect intergovernmental grants in several ways. The potential transmission channels discussed in this section and the implied qualitative impact of direct democracy on grants as compared to representative democracy are summarized in Table 1 . The first mechanism noted is the Wicksellian connection between spending and tax prices. Wicksell (1896) argued that the group of people who benefits from public goods should be equivalent to that paying the taxes to finance them and to that deciding on the provision of public goods. If this is the case, public goods can be efficiently provided such that citizens get the level and quantity of public goods they prefer and pay tax prices according to their marginal willingness to pay. If this is not the case, e.g., because of federal transfers targeted to the states, there are incentives for state taxpayers to demand a higher amount of public spending since they can 
Table 1. Transmission channels of direct democracy on spending and matching grants

\begin{tabular}{lll}
\hline & Spending & Matching grants \\
\hline Wicksellian connection & - & - \\
Cost exporting & \pm & \pm \\
Pork-barrel politics (Log-rolling) & - & - \\
Interest group influence & \pm & \pm \\
\hline
\end{tabular}

Notes. Theoretical transmission channels for democracy on spending and matching grants are reported. The qualitative impact of direct democracy on spending and matching grants as compaired to reprasentative democracy is indicated by a "+" for an increase in spending or matching grants, and a "-" for reductions of spending and matching grants.

externalize a part of the financing costs to other state taxpayers (for the theoretical framework of pork-barrel-politics see Weingast, Shepsle and Johnson, 1981). In the literature on the flypaper effect, the nature of voter's misperception induced by intergovernmental grants is similarly deduced from fiscal illusion (Heyndels and Smolders, 1994; Holsey, 1993; Oates, 1979). Voters try to estimate the marginal costs of public goods by their tax shares from the total costs of the public good. Accordingly, average costs of public goods are taken as a proxy for the marginal costs. When federal aid is paid to state and local governments in order to fund additional spending, the average costs of public goods for these voters will decrease while total costs increase. This discrepancy causes a misperception of the marginal costs by voters and creates a "grant illusion" (Holsey, 1993).

The more strongly spending and taxing decisions are separated, the more important such effects. Winer (1983) consequently argues that the perceived reduction in tax prices for public goods by federal grants to a particular state is due to the separation of spending and taxing decisions. He provides empirical evidence for Canadian provinces suggesting that the separation of spending and taxing introduced by federal grants caused a reduction of taxes and an increase in provincial expenditures. The same arguments are developed by Grossman (1990). He provides empirical evidence for a sample of 136 U.S. counties that an increase of the separation in taxing and spending by federal unconditional grants has a stimulating impact on local government spending. If the spending and taxing decisions are separated by federal grants, a basic Wicksellian connection cannot be sustained and spending increases.

In a pure representative democracy, spending and taxing decisions are indeed fully separated. Modern budgeting laws do not allow for earmarked taxes (for a review of the literature on earmarked taxation see Wagner, 1991). Tax revenue is budgeted in order to contribute to the financing needs determined by the spending side of the budget. Single spending projects are not linked to any revenue components. In addition, legislators are usually not 
perfectly following the preferences of citizens in their constituencies. Political competition between election days is not perfect. It enables representatives to pursue their own private interests or the narrowly defined interests of specific groups. Representative democracy thus aggravates the distorting effect of a separation of spending and taxing decisions and the Wicksellian connection between spending and taxation is already distorted without the consideration of intergovernmental grants.

When voters are enabled to directly participate in the political decisionmaking process they are however more strongly confronted with the costs of their decisions. This conjecture is illustrated by the very design of fiscal referendums for new spending projects in Swiss cantons. If the financial amount of a new spending project proposed by the government exceeds a certain threshold, a referendum has to take place (mandatory referendum) or could take place when a sufficient number of signatures from the electorate has been collected (optional referendum). In the referendum decision, voters decide upon potential volumes of the public outlay for a spending project and a combination of income or wealth tax increases with the issuing of new bonds. Different alternatives are frequently offered such that citizens can choose between alternative sizes of budget increases or reject the whole project when no alternative fits their preferences. Citizens are thus induced to compare the additional (marginal) spending and the additional (marginal) revenue requirement and evaluate whether the marginal benefit of the public services are at least equal to the marginal costs. By constitutional construction, fiscal referendums in Switzerland thus lead to a connection of spending and taxing decisions. In addition, the true costs of a specific spending project are in nearly all cases subject to public discussions prior to votes (Bohnet and Frey, 1994). As a consequence, if fiscal referendums are available for voters, the probability that they perceive the true costs of public goods is higher than in a pure representative democracies. Since matching grants involve a cofinancing of spending projects by the canton, fiscal referendums put an indirect restriction on matching grants as well. It can thus be hypothesized that fiscal referendums lead to lower spending and matching grants than pure representative democratic decision making because the Wicksellian connection between spending and taxing is stronger in direct democracy.

Indeed, Pommerehne and Schneider (1978) using data from the beginning of the seventies already found evidence for Swiss local jurisdictions that fiscal illusion is more pronounced in representative than in direct democracies and therefore is a more important reason for higher public spending in the former than in the latter system. While there is no recent evidence supporting their hypothesis, many studies report empirical results for Swiss cantons and local jurisdictions in the eighties and nineties that fiscal referendums are associated with lower public spending (e.g. Feld and Kirchgässner, 2001; Feld and Matsusaka, 2003; Schaltegger, 2001). ${ }^{1}$ Matsusaka (1995) also presents 
evidence that popular initiatives reduced public spending of U.S. states between 1960 and 1990. There is however no evidence yet on the impact of fiscal referendums on matching grants.

A second mechanism may shape the impact of direct democracy on intergovernmental grants. Grants from the federal government may disturb the equalization of marginal benefits and marginal costs of public services at the subcentral levels in democratic systems with and without referendums alike. In both cases, it could be argued that citizens and legislators have incentives to externalize the financing of public services to other jurisdictions. When the federal government pays at least partly for additional public services in a specific state, legislators and citizens may demand more spending than optimal because they have not to incur full costs of the project. More pointedly, it can be argued that fiscal referendums lead to an increased demand for matching grants because selfish citizens fully recognize the possibility to externalize the costs of spending projects to the whole populace. This kind of cost exporting indirectly increases the size of the spending projects as well.

This argument, however, only holds in a static perspective in which citizens are assumed to be myopic. In a dynamic perspective, citizens will realize that higher federal grants have to be financed by higher federal taxes, as the citizens pay taxes on all government levels and decide also on public services at the same government levels. These elements of direct democracy reduce the danger of different agents overusing the fiscal commons. This is different in a system of representative democracy where state representatives and federal representatives are seldom identical. State representatives thus have incentives for attempting to present additional federal funds for new spending as a success to their constituencies. In addition, they have extended possibilities to engage in a log-rolling exercise with representatives from other states. Such a log-rolling can particularly take place in a two chamber system where the second chamber of parliament provides an arena to coordinate the negotiations of different state representatives. It allows them to collude against the federal government and/or particularly rich states and therefore provides additional possibilities to increase spending. Such a log-rolling is very much reduced by fiscal referendums where the arena for log-rolling is lacking.

It is hence theoretically open whether fiscal referendums reduce or increase the size of grants. The stronger Wicksellian connection in direct democracy is speaking for less grants, in particular if matching grants are used by the federal government. The possibility for cost exporting provides incentives to demand higher grants if citizens are short sighted and to demand less grants if citizens are far sighted. Log-rolling possibilities are reduced in direct democracy such that less grants result. The overall effect of direct democracy is hence indeterminate: If citizens' short sightedness dominates all other effects, grants received by direct democratic cantons will be higher. If any of the other 
mechanisms dominated, grants received would be less. This leads us to the first empirically testable hypothesis:

Hypothesis 1: The amount of received grants by a state is smaller under a regime of direct democracy with fiscal referendums, than under representative democratic circumstances where the budget process is determined by representatives.

In the budgetary setting described above, interest groups are not considered. It is, however, well known from the discussion among political scientists, particularly in the United States, that there is a significant interest groups influence in political decision making. Some authors are very critical on the political influence of particular interests (Bernholz, 1995; Olson, 1982). They fear an excessive use of the public budget as a common pool due to the pressure by special interest groups. On the other hand, Becker (1983) argues that the competition between pressure groups favors efficient results in the political system since it allows for different preference intensities with respect to public goods.

The impact of interest groups in a direct democracy is highly disputed in the literature. The discussion dates at least back to James Madison's arguments against direct democracy in the Federalist Papers: "From this view of the subject it may be concluded that a pure democracy, by which I mean a society consisting of a small number of citizens, who assemble and administer the government in person, can admit of no cure for the mischief of faction." (Federalist 10, Hamilton, Madison and Jay, 1787/1788, p. 81). In Switzerland, Borner, Brunetti and Straubhaar $(1990,1994)$ contend that powerful interest groups have a strong impact on policy outcomes in a direct democracy by using the threat of an optional referendum. According to their analysis, political decision in a direct democracy are biased towards the interests of powerful pressure groups without having an explicit democratic legitimacy. Implicitly, this analysis assumes that the impact of interest groups is less powerful when referendum possibilities are not available. However, in a comparative perspective, the impact of interest groups is not at all clear. These groups influence policies in both representative and direct democracies. On the one hand, their impact is more visible in direct legislation than in representative democracies because their positions are discussed openly in referendum campaigns. On the other hand, interest groups influence drafted bills in the public administration and by convincing (or bribing) legislators already at early stages of the legislative process.

Another argument is widely debated among (American) political scientists. Since referendum campaigns are costly, particularly well organised and wealthy interest groups have the ability to successfully run referendum campaigns. In the United States, it is obvious that interest groups attempt to 
influence referendum and initiative outcomes. Smith $(1998$, p. 79) claims that proponents and opponents of Proposition 13 spent US \$2 million to influence the initiative outcome. According to Boehmke (1999), California's Proposition 5 for the allowance of Indian gambling casinos in 1998 consumed $\$ 50$ million of campaign spending. Zisk (1987, p. 90$)$ states that $80 \%$ of the 50 referendums and initiatives held between 1976 and 1980 in different U.S. states were decided in favor of the interest groups that spent more money than their opponents. However, Lydenberg (1979), Lowenstein (1982), Shockley (1985) and Cronin (1989, p. 99) ascertain that financial superiority does in general not suffice to get citizens' approval on a certain proposal. Their evidence is supported by Gerber (1999). On the basis of campaign contributions to 161 ballot measures between 1988 and 1992 in eight U.S. states, she presents evidence that economic interest groups as opposed to citizen interests use direct legislation less often to pass new laws by initiatives and more often to preserve the status quo or to pressure legislatures. Moreover, direct policy consequences in these ballot measures may be more strongly attached to citizen than to economic groups. Economic groups are not able to pass new initiatives, whereas citizen groups are more successful in doing so. Economic groups have more success in blocking measures through opposition spending. There is similar evidence for Switzerland. In many examples, citizens voted against the proposal of political and economic elites despite their high financial involvement and political dominance in the debates. In a survey on the Swiss literature, Longchamp (1991) concludes that referendums and initiatives cannot be simply "bought" by interest groups. Nevertheless, wealthy interest groups have better possibilities to finance referendum campaigns than poor ones. In a comprehensive analysis, Schneider (1985) derives the result that the impact of interest groups becomes strongly visible in referendums and initiatives. However, the impacts of different groups are frequently running in opposite directions and often compensate for each other.

On the whole, it is undisputed that interest groups have an impact on policy outcomes in direct democracy. It is however fully open to debate whether the impact is stronger or less intense in direct than in representative democracies. A systematic comparison of the impact of interest groups on the decisions of parliaments, governments and bureaucracies on the one hand as compared to initiatives and referendums on the other hand is one of the totally blank areas of research on direct democracy up to now. The question is whether there is a significant difference in interest group influence on policy outcomes in both systems.

Thus, there is no unchallenged prediction of the strength of interest group influence in both systems. Interest group influence could be stronger in a system of representative or of direct democracy, but could also be the same. In addition, how the differences extend to the grant system is ambiguous. If specific interest groups lobby for a new spending project partly subsidized by 
the federal government, they may be able to convince citizens in a referendum to support their position. This may be the case, e.g. when interest groups are concentrated in a certain state. As in the general case discussed earlier, citizens can be expected to realize in the medium run that interest groups in other states attempt similar things leading to a higher federal tax burden. Again the possibilities for log-rolling between the different states are pretty much reduced in a direct democratic system such that the impact of interest groups in direct democracies should be lower as well. This leads us to the second hypothesis:

Hypothesis 2: The demand for federal grants that can be traced back to the impact of specific interest groups is lower under a regime of direct democracy where the fiscal referendum is available, than under representative democratic circumstances where the budget process is determined by representatives.

\section{Intergovernmental Grants and Institutional Variation}

In order to test the two hypotheses formulated earlier, we investigate the Swiss system of intergovernmental grants. Swiss federalism is characterized by a far reaching fiscal autonomy at the state and local levels. The states (cantons) have the basic power to tax personal and corporate income as well as capital while the local jurisdictions levy a surcharge on the cantonal income tax and raise own wealth and property taxes. The federal government mainly relies on indirect (proportional) taxes but also on a highly progressive income tax. In addition, it levies a source tax on capital income by a uniform rate of $35 \%$ that could be deducted by tax payers when declaring their income to the cantonal tax administration.

The Swiss system of intergovernmental grants on the federal level has been established in 1959. Today, it consists of a complex system of almost exclusively vertical transfers from the federal government to the 26 cantons. There is no horizontal equalization system in Switzerland, but only specific horizontal intercantonal payments for particular services. However, the vertical transfers have a strong horizontally equalizing impact since rich cantons bear most of the financial burden of the system. The system of intergovernmental grants has four main "pillars": The federal contributions to the cantons, the cantonal share of federal revenues, the cantonal share of the gains from the central bank and cantonal contributions to the federal social security system. $30 \%$ of the highly progressive federal income tax is directly redistributed to the cantons according to income (17\%) and to financial prosperity of the canton (13\%). The federal source tax on capital income is distributed in a similar fashion to the cantons, but instead of financial prosperity the population is taken into account. Both grants are lump-sum and only 
the first component is not following fiscal equalization criteria. The remaining $70 \%$ of the revenue from the federal income tax are used to fund matching grants.

The share of grants from total cantonal revenue is reported in the second column of Table 2 where cantons are listed according to their financial strength. In some of the financially weak cantons, for example Uri and Jura, grants account for almost half of the total cantonal income. Other cantons like Zurich, Geneva or both Basel fund their spending to more than $85 \%$ by own taxes. On average, grants cover less than a quarter of total cantonal revenue. As Table 2 also indicates, on average three quarters of all federal transfers take the form of matching grants. Again there is an interesting variation ranging from 38\% in the case of Zug to almost $90 \%$ in the case of Uri. Zug appears to be an outlier since the share of matching grants is at least $50 \%$ in the other cantons. Comparing the descriptive figures for Zug it becomes obvious that this canton is obtaining a relatively large amount of lump-sum grants from the federal government.

The amount of matching grants received by a canton depends on an index which should reflect cantonal prosperity. This index relies on four components: cantonal income, cantonal tax revenues adjusted by the cantonal tax burden, the cantonal tax burden itself and an index reflecting the share of mountainous areas in a canton. The index of financial prosperity and its subindex of mountainous areas are presented in the two last columns in Table 2. The index of financial prosperity determines the order of cantons in the table. The Swiss average is set to 100 index points, while the deviations from the average determine the range of the index. It ranges from 216 in Zug to 30 index points in the canton of Valais. The financial strength of Zug is more than seven times that of the Valais. It is also obvious from Table 2 that neither financial prosperity nor the variance of it can be fully explained by the share of mountainous area in a canton. This latter range is much lower and the richer half of the cantons appears to be assessed as having a lower share of mountains.

Aside the structure of its fiscal federalism including the grant system, Switzerland is known for its considerable variation of institutions of direct democracy. Most cantons have some form of semi-direct democracy with a parliamentary system with legislators elected according to a system of proportional party representation. Only two rural cantons (Appenzell-Innerrhoden (AI) and Glarus (GL)) take political decisions in canton meetings (Landsgemeinde). On the other hand, the cantons have different institutions of political participation rights (Feld and Matsusaka, 2003; Trechsel and Serdült, 1999). Proposals can be initiated by the voter initiative, and new laws passed by the legislature are, to different degrees, subject to an optional or even a mandatory popular referendum.

In the context of our analysis, the impact of fiscal referendums on policy decisions of sub national governments is of interest. The relevant information 
Table 2. Federal index of financial prosperity and federal transfer index for mountainous areas (for 2002/2003), share of grants in the total cantonal revenues and share of conditional grants, 1999

\begin{tabular}{|c|c|c|c|c|}
\hline cantons & $\begin{array}{l}\text { Share of grants } \\
\text { from total } \\
\text { Cantonal } \\
\text { revenues }(\%)\end{array}$ & $\begin{array}{l}\text { Share of } \\
\text { matching } \\
\text { grants } \\
(\%)\end{array}$ & $\begin{array}{l}\text { Federal index of } \\
\text { financial prosperity } \\
(\text { Swiss average }= \\
100)\end{array}$ & $\begin{array}{l}\text { Federal index } \\
\text { of mountainous } \\
\text { areas (Swiss } \\
\text { average }=100)\end{array}$ \\
\hline \multicolumn{5}{|c|}{ Financially strong cantons } \\
\hline Zug & 26.1 & 38.4 & 216 & 96.70 \\
\hline Basel-City & 10.8 & 71.2 & 173 & 111.03 \\
\hline Zurich & 15.1 & 66.5 & 160 & 108.95 \\
\hline Geneva & 9.7 & 61.1 & 141 & 111.08 \\
\hline Nidwalden & 39.6 & 82.6 & 129 & 84.12 \\
\hline Basel-Land & 15.0 & 71.4 & 120 & 105.37 \\
\hline \multicolumn{5}{|c|}{$\begin{array}{l}\text { Cantons with average } \\
\text { financial potential }\end{array}$} \\
\hline Schwyz & 40.4 & 51.3 & 112 & 85.67 \\
\hline Schaffhausen & 17.7 & 69.8 & 107 & 111.03 \\
\hline Aargau & 19.3 & 70.8 & 97 & 110.43 \\
\hline Vaud & 19.1 & 77.4 & 94 & 106.22 \\
\hline Thurgau & 25.7 & 77.3 & 83 & 110.40 \\
\hline Solothurn & 26.8 & 77.8 & 82 & 103.42 \\
\hline Glarus & 26.8 & 59.0 & 82 & 77.16 \\
\hline Ticino & 23.3 & 74.1 & 82 & 86.06 \\
\hline St. Gallen & 24.9 & 79.5 & 80 & 98.73 \\
\hline Graubünden & 47.1 & 87.7 & 77 & 70.00 \\
\hline Luzern & 27.9 & 77.0 & 67 & 102.12 \\
\hline Uri & 48.8 & 89.7 & 64 & 73.55 \\
\hline Appenzell a.Rh. & 29.6 & 69.8 & 63 & 82.03 \\
\hline Appenzell i.Rh. & 38.7 & 80.1 & 62 & 71.33 \\
\hline \multicolumn{5}{|c|}{ Financially weak cantons } \\
\hline Bern & 28.2 & 78.9 & 57 & 94.05 \\
\hline Neuchâtel & 38.8 & 81.7 & 55 & 88.56 \\
\hline Fribourg & 35.3 & 80.1 & 51 & 97.09 \\
\hline Obwalden & 44.5 & 79.3 & 35 & 76.83 \\
\hline Jura & 48.6 & 84.8 & 34 & 84.98 \\
\hline Valais & 41.7 & 72.8 & 30 & 81.4 \\
\hline Switzerland & 23.1 & 74.9 & 100 & 100 \\
\hline
\end{tabular}

Source. Swiss Federal Finance Department, 1999.

Notes. The federal index of financial prosperity consists of four subindices. The federal transfer for mountainous areas is one out of four. The lower the number of the index the higher the amount of transfers a canton receives. 
Table 3. The budget referendum thresholds in Swiss cantons

\begin{tabular}{|c|c|c|c|c|c|}
\hline \multirow{2}{*}{ Canton } & \multicolumn{2}{|c|}{ Nonrecurring expenditures ${ }^{b}$} & \multicolumn{2}{|c|}{ Recurring expenditures $^{b}$} & \multirow[t]{2}{*}{ Frey-Stutzer index ${ }^{a}$} \\
\hline & Optional & Mandatory & Optional & Mandatory & \\
\hline $\mathrm{ZH}$ & $2-20$ & 20 & $0.2-2$ & 2 & 4 \\
\hline $\mathrm{BE}$ & 2 & & 0.4 & & 5 \\
\hline LU & $3-25$ & 25 & Specific stipulations & & 4.25 \\
\hline UR & 0.5 & 1 & 0.05 & 0.1 & 5 \\
\hline SZ & & 0.25 & & 0.05 & 4.38 \\
\hline OW & 0.5 & 1 & 0.1 & 0.2 & 5 \\
\hline NW & 0.25 & 5 & 0.05 & 0.5 & 5 \\
\hline GL & & 0.5 & & 0.1 & 4 \\
\hline ZG & & 0.5 & & 0.05 & 4 \\
\hline FR & $0.25 \%$ & $1 \%$ & $0.25 \%$ & $1 \%$ & 2 \\
\hline $\mathrm{SO}$ & $1-2$ & 2 & $0.1-0.2$ & 0.2 & 5 \\
\hline BS & 1 & & 0.2 & & 4.25 \\
\hline $\mathrm{BL}$ & 0.5 & & 0.05 & & 4.75 \\
\hline $\mathrm{SH}$ & $0.3-1$ & 0.3 & $0.05-0.1$ & 0.05 & 4.5 \\
\hline $\mathrm{AR}$ & & $5 \%$ & & $1 \%$ & 4 \\
\hline AI & 0.25 & 0.5 & 0.05 & 0.1 & 3 \\
\hline SG & $3-15$ & 15 & $0.3-1.5$ & 1.5 & 3.25 \\
\hline GR & $1-5$ & 5 & $0.3-0.5$ & 0.5 & 4 \\
\hline AG & 3 & & 0.3 & & 4.5 \\
\hline TG & 1 & 3 & 0.2 & 0.6 & 4.5 \\
\hline TI & 0.2 & & 0.05 & & 2.75 \\
\hline VD & & & & & 3 \\
\hline VS & $0.75 \%$ & & $0.25 \%$ & & 1 \\
\hline $\mathrm{NE}$ & & $1.5 \%$ & & $1.5 \%$ & 1.5 \\
\hline GE & 0.125 & & 0.06 & & 1 \\
\hline $\mathrm{JU}$ & $0.5 \%$ & $5 \%$ & $0.05 \%$ & $0.5 \%$ & 2.5 \\
\hline
\end{tabular}

Source. G. Lutz and D. Strohmann (1998); B. S. Frey and A. Stutzer (2000).

${ }^{a}$ The index is constructed by the signature requirement as the number of signatures relative to the number of voters, by the days within which the signatures have to be collected and by the financial threshold as the per capita spending limit allowing for referendum (the values correspond to the year 1992).

${ }^{b}$ In million Swiss Francs if not indicated otherwise.

on the fiscal referendum is provided in Table 3. There exists no fiscal referendum on the central level, but with the exception of the canton of Vaud $(\mathrm{VD})^{2}$ all cantons know a derivative of the fiscal referendum. Of the remaining 25 cantons, 13 have a mandatory as well as an optional fiscal referendum. In seven other cantons (BE, BS, BL, AG, TI, VS, GE) only the optional fiscal 
referendum is possible, whereas in SZ, GL, ZG, AR, NE new spending projects have to pass the mandatory, but not the optional fiscal referendum. The fiscal referendum can be differentiated according to five categories: the fiscal referendum for public spending, public-sector bonds, taxes, holdings on enterprises and for purchases of real estate. In principle, there are threshold variations for nonrecurring expenditures and for recurring expenditures. Five cantons (FR, AR, VS, NE, JU) determine thresholds as a percentage of last budget's expenditures. All others determine a specific amount as the decisive threshold. The number of signatures required to qualify for ballots and the timespan within which the signatures have to be collected for the optional fiscal referendum is also very diverse among cantons. The number differs from $0.49 \%$ of signatures from all voters in the canton of Obwalden (OW) to $4.28 \%$ in the canton of Jura (JU), while the time span for collecting the signatures varies from 30 to 90 days. This institutional variation provides a laboratory to investigate the impact of fiscal referendums on the amount of federal grants to the cantons and its interaction with interest group influence.

\section{Empirical Model}

On the basis of the Hypothesis 1, according to which fiscal referendums are associated with a lower degree of intergovernmental transfers, we use a loglinear model for the amount of cantonal grants per capita. The following equation is proposed in order to test Hypothesis 1:

$$
G_{i t}=\alpha_{1}+\beta_{1} R_{i t}+\gamma_{1} I_{i t}+\delta_{1} X_{i t}+\varepsilon_{1 i t}
$$

where $G_{i t}$ denotes the amount of federal grants per capita received by the cantons. As noted above, federal grants consist of three basic components: lump-sum grants with redistribution according to equalization needs, lumpsum grants without redistribution and matching grants. We use only matching grants in our empirical analysis since the political impact of cantons on the determination of the lump-sum grants is negligibly small. The share of lumpsum and matching grants is constitutionally fixed to 30 and $70 \%$ respectively, and the shares of lump sum transfers with and without redistribution have remained nearly constant during the last 20 years such that cantonal politics can only influence lump-sum grants in the long-run by an impact on federal political decisions. This is different in the case of matching grants. Because they must be cofinanced by the cantons, a canton has a strong influence on the amount of matching grants obtained from the federal level.

$R_{i t}$ is a dummy variable that takes on the value of one if the cantonal constitution contains a mandatory fiscal referendums, and zero otherwise. It is one of the main variables of interest and is hypothesized to have a negative impact on grants. In addition, the spending thresholds for nonrecurring 
expenditures are included because they differentially indicate how restrictive the fiscal referendum could be (Feld and Matsusaka, 2003). The higher the spending threshold, the less binding a fiscal referendum is. The spending threshold is thus expected to have a positive impact on matching grants. $I_{i t}$ is a vector of three different variables representing the power of interest groups in a canton. Following Grossman (1994) we include the share of the cantonal administrations' employees in the total cantonal population as a proxy of the power of the cantonal bureaucracy. Since the bureaucracy obtains a higher discretionary power by disposing of additional public funds, it exerts a stronger demand for grants. Moreover, lobbying for grants at the federal level requires the hiring of additional personnel in the state bureaucracy. The respective increase in the number of bureaucrats further raises the power of the bureaucracy (Niskanen, 1971). That's why the bureaucracy is asking for an extension of the federal grant system as well. Hence, we expect the state bureaucracy variable to exert a positive impact on matching grants per capita. The larger the cantonal bureaucracy, the more easily a canton can develop new spending projects specifically designed to capture federal funds. Moreover, this canton can more easily send bureaucrats to the Swiss capital in order to present the projects to federal agencies and to lobby for funds.

The second proxy for the power of interest groups in the model is the share of union members from total cantonal population. There is plenty of anecdotal evidence in federal countries and also in Switzerland that states (cantons) facing structural shifts of their economies attempt to shift the burden of structural economic reform to the whole country. A recent Swiss example of a very successful attempt to externalize the costs of structural adjustments concerns the "Swissair-crisis" in 2001. Because of insolvency as well as a high burden of debts, the national air carrier "Swissair" went bankrupt. After some well-organized demonstrations of the unions, the federal government granted subsidies to the employees as well as a huge financial assistance of about 2 billion CHF to build a new national airline company even though the benefits of the Swiss aviation industry are mainly concentrated in the canton of Zurich. Furthermore, besides the federal government, other cantonal governments than Zurich had been demanded to pay a share of the assistance as well. ${ }^{3}$ An important role in such burden-shifting attempts is played by trade unions. Their main focus is on the number of jobs in an industrial sector or in a region. Despite the fact that union members in other regions would have to pay for their colleagues in a specific canton, unions manage to keep them sticking to solidarity. A very comfortable method of externalizing the adjustment costs of structural shifts can be found in federal grants to the states. We therefore expect union membership to exert a positive impact on federal grants. Third, the share of farmers from total employment is taken as a proxy for interest group influence. Swiss farmers are known as one of the most influential interest group in the country. It could thus well be that they 
successfully lobby for more grants because this is indirectly helping them to keep their high incomes. However, farmers get direct subsidies from the federal level such that they will not need to lobby for higher grants. The impact of farmers is thus indeterminate.

$X_{i t}$ is a vector of political, economic and demographic control variables. The number of seats of a canton in the federal parliament (in percent of population) is included to control for the cantonal influence on policy outcomes at the federal level. The more representatives a canton has in the federal legislature, the more important is its political weight in pork barrel politics. Political preferences of the cantonal constituencies are controlled for by including an ideology proxy. Ideology is measured by the relative strength of parties in the government. The stronger leftist parties, the higher the value of this variable. Given the ideological closeness between leftist parties and trade unions, similar arguments hold. It could thus be expected that the ideology proxy exerts a positive influence on federal grants.

In addition, we control for cantonal income per capita, the share of the population older than 65 , the share of the urban population, cantonal unemployment rates, and a language variable indicating the share of the German speaking population in a canton. Moreover, the share of employed inhabitants in a canton is included in order to control for the extent that trade unions deviate from the interests of the employees they pretend to represent. Also, the index of mountainous areas is included in order to control for the politically perceived extent of mountains in a canton. Please note from Table 2 that this index takes on higher values for cantons with smaller mountain areas and should thus be expected to have a negative sign on matching grants. We also included dummy variables for outliers. The estimation results indicated that only the canton of Lucerne proved to be an outlier. The results of that dummy variable are not reported. In all equations, time fixed effects are included. $\alpha, \beta, \gamma, \delta$ are vector valued coefficients to be estimated while $\varepsilon$ represents an error term. The unit of observation is the cantonal level. We estimate the model using annual data over the period 1980 to 1998 deflating all financial variables to the year 1980 . The subscript $i=1, \ldots, 26$ indicates cantons and $t=1980, \ldots, 1998$ indexes years. The estimations are performed using OLS by correcting the standard errors by a heteroscedasticity and autocorrelation consistent covariance matrix.

\section{Results}

The testing strategy consists of three steps. First, the basic model is estimated including the variables mentioned in the previous Section. This model allows us to test Hypothesis 1 on the impact of fiscal referendums on federal matching grants. In addition, the impact of interest groups, in our case the state bureaucracy and trade unions, on federal matching grants can be analyzed. 
Second, the sample is split in cantons with and those without mandatory fiscal referendums. The same econometric model (without the fiscal referendum variables of course) is estimated for both sub-samples in order to be able to perform a quantitative simulation how much matching grants a representative democratic canton would have obtained if it included a mandatory fiscal referendum in its constitution. Third, the model is enriched with interaction terms between the fiscal referendum dummy and the three interest group variables. These interaction variables are used to test the differential impact of interest groups in cantons with and without fiscal referendums. They thus provide a test of Hypothesis 2.

The results of the basic model are presented in Table 4. According to these estimates, cantons with fiscal referendums get significantly lower matching grants. This effect is significant on the $10 \%$ level. In addition, the spending threshold has the expected positive effect and is significant on the 5\% level. The more easily a spending project triggers a mandatory fiscal referendum because of a low-spending threshold, the lower are matching grants received. According to the $F$-test statistic at the bottom of Table 4, the hypothesis that both variables do not jointly influence matching grants can be rejected at the $5 \%$ significance level. On the basis of these results, Hypothesis 1 cannot be rejected. The fiscal referendum is also restricting cantonal spending projects that are cofinanced by federal grants. This effect becomes the more pronounced the lower the spending threshold is.

The expected influence of cantonal interest groups is only partially supported by the estimation results. The higher the number of employees in cantonal administrations as compared to total population, the higher the received matching grants. The impact of the cantonal bureaucracy is significant on the $1 \%$ level. A rise of the share of cantonal employees by $10 \%$ is accompanied by an increase of federal transfers by $6.2 \%$. Union density is however not significantly different from zero. Similarly, the share of total cantonal employment on the received matching grants is not significantly different from zero. The share of farmers from total employment is associated with significantly less matching grants from the federal level (at the 10\% level). It appears that the additional subsidies received from federal agricultural policy are at least partially compensated for by lower matching grants. The quantitative effect of this variable is relatively important.

The number of seats in the federal parliament (in percent of population) is significant on the 5\% level and has a negative impact on matching grants. Surprisingly, a better representation at the federal level is associated with a lower amount of matching grants. This effect is however quantitatively unimportant. Leftist parties demand higher grants as well. The stronger leftists are represented in the cantonal government, the higher are real matching grants per capita. Quantitatively, the demand of leftist parties for matching grants is non-negligible. An increase in the share of leftist parties by $10 \%$ is associated 
Table 4. Log linear regressions of real federal matching grants on fiscal referendums and interest group influence, 26 cantons, 1980-1998

\begin{tabular}{|c|c|c|c|c|}
\hline Variables & Full sample & $\begin{array}{l}\text { Cantons } \\
\text { with fiscal } \\
\text { referendums }\end{array}$ & $\begin{array}{l}\text { Cantons } \\
\text { without fiscal } \\
\text { referendums }\end{array}$ & Full sample \\
\hline Fiscal referendum & $-0.042^{*}(1.85)$ & - & - & $-0.052^{* *}(2.11)$ \\
\hline Spending Threshold & $0.006^{* *}(2.12)$ & - & - & $0.005^{*}(1.65)$ \\
\hline $\begin{array}{l}\text { Employees of } \\
\text { the cantonal } \\
\text { administration }\end{array}$ & $0.624^{* * *}(6.98)$ & $0.340^{* *}(2.70)$ & $0.643^{* *}(2.21)$ & $0.647^{* *}(6.98)$ \\
\hline Union members & $0.931(0.70)$ & $2.214(1.23)$ & $-2.007(0.58)$ & $-0.677(0.325)$ \\
\hline Farmers & $-5.608^{*}(1.91)$ & $-8.041^{*}(1.67)$ & $5.208(1.29)$ & $-5.003(1.37)$ \\
\hline $\begin{array}{l}\text { Fiscal referendums* } \\
\text { Employees of } \\
\text { the cantonal } \\
\text { adminstration }\end{array}$ & - & - & - & $0.009(0.27)$ \\
\hline $\begin{array}{l}\text { Fiscal referendums* } \\
\text { Union members }\end{array}$ & - & - & - & $1.738(0.96)$ \\
\hline $\begin{array}{l}\text { Fiscal referendums* } \\
\text { Farmers }\end{array}$ & - & - & - & $-1.480(0.48)$ \\
\hline $\begin{array}{l}\text { Number of seats in the } \\
\text { federal parliament }\end{array}$ & $-0.007^{* *}(2.11)$ & $0.012(1.58)$ & $0.002(0.15)$ & $-0.008^{*}(1.96)$ \\
\hline Ideology & $-0.149^{* * *}(4.26)$ & $0.152^{* *}(2.25)$ & $0.151^{*}(1.75)$ & $0.150^{* *}(3.47)$ \\
\hline Cantonal income & $-1.063^{* *}(5.06)$ & $-0.706 *(1.75)$ & $-0.764^{* * *}(3.62)$ & $-1.019(4.92)$ \\
\hline $\begin{array}{l}\text { Share of population } \\
\text { older than } 65\end{array}$ & $0.008(0.58)$ & $0.007(0.28)$ & $0.037(1.39)$ & $0.017(0.97)$ \\
\hline Urban population & $-0.198(1.13)$ & $-0.868^{* *}(2.28)$ & $-0.120(0.30)$ & $-0.162(0.88)$ \\
\hline $\begin{array}{l}\text { Federal transfer } \\
\text { index for } \\
\text { mountainous areas }\end{array}$ & $-0.019^{* * *}(6.91)$ & $-0.028^{* * *}(7.42)$ & $-0.007(1.06)$ & $-0.018^{* * *}(6.04)$ \\
\hline Unemployment & $-0.040(1.34)$ & $0.056(1.39)$ & $-0.046(1.58)$ & $-0.045(1.42)$ \\
\hline Employment & $-0.833(0.55)$ & $-3.174^{* * *}(3.19)$ & $-2.010(0.70)$ & $-1.476(1.02)$ \\
\hline Language & $-0.002(1.23)$ & $-0.002(0.76)$ & $-0.003^{* * *}(2.83)$ & $-0.002(-1.11)$ \\
\hline $\begin{array}{l}F \text {-test: fiscal } \\
\text { referendum }\end{array}$ & $4.594^{* *}$ & - & - & 2.132 \\
\hline $\begin{array}{l}F \text {-test: Employees of the } \\
\text { cantonal adminstration }\end{array}$ & - & - & - & $24.502^{* * *}$ \\
\hline$F$-test: Union menmbers & & & & 0.572 \\
\hline$F$-test: Farmers & - & - & - & 1.982 \\
\hline $\operatorname{Adj} . R^{2}$ & 0.853 & 0.848 & 0.863 & 0.854 \\
\hline Jarque-Beta & 3.561 & 0.016 & 0.245 & 2.152 \\
\hline Observations & 494 & 339 & 155 & 494 \\
\hline
\end{tabular}

Note. $t$-values are given in paranthesis. The computed standard errors have been corrected for Newely West's heteroskedasticity and serial correlation consistent covariance matrix. All regressions contain 19 year-dummies whose coefficients are not reported. ${ }^{* * *, * * * *}$ indicate significance at $1 \%, 5 \%$, and $10 \%$ levels, respectively. The Jarque-Beta test statistic is a test on the null hypothesis of normally distributed residuals. 
with an increase in real matching grants per capita by $1.5 \%$. Probably, leftwing parties are more successful in redistributive rent seeking at the federal level. But it is also possible that cantonal constituencies do more likely vote for leftist parties when facing structural problems eventually justifying federal funds from a political point of view.

The remaining control variables show a reasonable pattern of influences on grants. The richer a canton, the less it receives from the grants system. This effect is significant at the $1 \%$ level. The estimated income elasticity of about-1.1 reflects the intended redistributive effect of the Swiss intergovernmental grants system. Demographic variables do not have any impact on grants. The share of people older than 65, the share of the urban population, unemployment and the language variable are not significant. The federal index of mountainous area in a canton is however highly significant on the $1 \%$ level. It is not really surprising that this index has a strong impact since it is a constitutional feature of the grants system in Switzerland. It is more important to note that the results of the other variables remain robust to the inclusion of the index. In total, the model explains about $85 \%$ of the variance of matching grants. The hypothesis of normal distribution of the residuals cannot be rejected at any conventional significance level (after controlling for the canton of Lucerne). Several robustness tests have been performed. We additionally included a variable measuring the intensity of tax competition among the cantons together with the fragmentation of a canton in the number of communities. Both did not have any effect on matching grants. Traditional federalism arguments apparently do not play any role for Swiss fiscal equalization. Similarly, population size remained insignificant in all estimations. The results remained relatively robust.

Splitting the sample in the cantons with and without fiscal referendums, interesting results are obtained. The results are reported in columns 2 and 3 of Table 4. In both equations, the share of cantonal public employment exerts a highly significant positive impact on the size of federal matching grants that a canton receives. The impact is however quantitatively different in cantons with and without fiscal referendums. In cantons with fiscal referendums (column 2 ), a rise of the share of cantonal employees by $10 \%$ is accompanied by an increase of federal transfers by $3.4 \%$. In cantons without fiscal referendums, this effect almost doubles. Farmers induce significantly less matching grants in cantons with fiscal referendums only, while this variable has a positive sign for cantons without fiscal referendums though without reaching any conventional significance level. The impact of trade unions is insignificant for both groups of cantons. The control variables remain more or less robust in both subsamples as compared to the estimations of the basic model for the whole sample.

In the second step, the estimation results for the subsample of cantons with fiscal referendum are taken to simulate the amount of matching grants of the representative democratic cantons if they switched to direct democracy. 


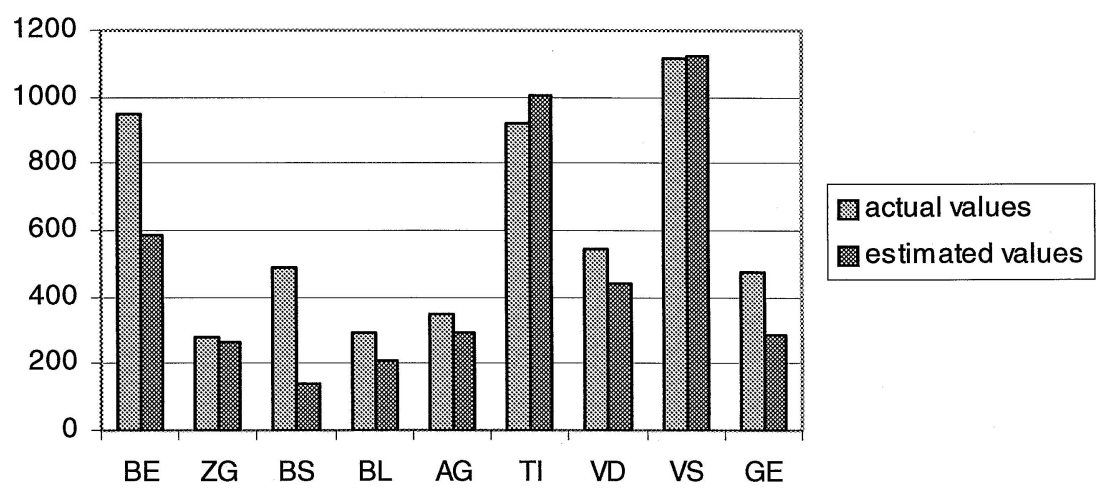

Figure 1. Actual and simulated values of matching grants per capita for representative democratic cantons and their assumed shift to direct democracy.

The simulation results are presented in Figure 1. It can be seen that 7 out of 9 cantons without fiscal referendum would have received considerably less matching grants if they had adopted a fiscal referendum in their constitution. Only in the case of the Ticino, a higher amount of matching grants could have been expected. In the case of the Valais, virtually no difference would have resulted. The effect of the fiscal referendum is quantitatively important. For example, the canton of Bern would have received real matching grants of 585 SFr per capita on average for the years 1980 to 1998 instead of 949 SFr. This is a reduction of nearly $40 \%$. Basel City would have received $141 \mathrm{SFr}$ per capita instead of $488 \mathrm{SFr}$, Geneva $290 \mathrm{SFr}$ instead of $476 \mathrm{SFr}$ if it switched to the fiscal referendum, the Vaud 441 SFr instead of $543 \mathrm{SFr}$. In the remaining cases, the effect of the introduction of a fiscal referendum would have been less important. Still, the effect is more important than the mere estimation result from Table 4 might appear.

In the third step, the interaction terms of fiscal referendums with the cantonal bureaucracy, union density and the share of farmers in a canton are included in the basic model in order to test Hypothesis 2. The estimation results of that model are presented in column 4 in Table 4 . Comparing the results of the first equation with those in column 4 , it becomes obvious that the structure of the estimation results does not change considerably. The results of the covariates remain relatively robust even in the quantitative sense. Because the model is only augmented by the interaction terms it makes sense to focus on fiscal referendums and state interest groups. In order to check whether one of these variables has an impact on grants it is necessary to test the joint significance of the three variables in the case of fiscal referendums or two variables in the case of state interest groups in which the variables of interest appear. The $F$-tests on joint significance are again reported at the bottom of Table 4 .

According to the $F$-statistics, only the joint significance of the cantonal bureaucracy cannot be rejected on any conventional significance level. The 
fiscal referendum variables are only marginally significant. Still the fiscal referendum dummy and the spending threshold keep their significant baseline effects even if the fiscal referendum is not significant in the interaction with interest group variables. Farmers and unions are not jointly significant each. All in all, these results do not allow to reject Hypothesis 2, but they do also not provide evidence in favor of the hypothesis that fiscal referendums restrict interest group influence.

\section{Conclusions}

In this paper, we have analyzed to what extent fiscal referendums restrict the impact of interest groups in the determination of intergovernmental grants on the basis of a data set of the 26 Swiss cantons from 1980 to 1998. We have found evidence that fiscal referendums lead to lower matching grants. Matching grants are particularly vulnerable to the state bureaucracy and leftist parties in Switzerland. Other state interest groups do not have a significant impact on matching grants. Our results do also not provide strong support for the hypothesis that fiscal referendums reduce the impact of interest groups. The only weak evidence that can be observed is that the quantitative impact of the state bureaucracy in cantons with fiscal referendums is much lower than in cantons without fiscal referendums. This effect is however not supported by estimations with the interaction terms. The effect of fiscal referendums on matching grants thus appears to be the result of a stronger Wicksellian connection in direct democracy and the reduced ability to conduct pork-barrel politics.

Hence, these results indicate the usefulness of fiscal referendums also with respect to interest group influence. Given the debate about the differential impact of interest groups in direct and representative democracies among political scientists and economists dating back at least to James Madison, our results are encouraging. The result suggests that interest groups don't have a stronger effect in direct democracy than in representative democracy, although they are not particularly restricted by referendums. Although referendums can much more easily be used by specific interests to preserve the status quo than initiatives, it appears that the overall effect of referendums, at least in the case of grants, is a disciplining effect on interest groups. Voters impose a hard budget constraint on political actors. Thus, the argument cannot be sustained that a switch from a pure representative democratic system to a system with fiscal referendums is not feasible because it would unduly increase the impact of interest groups. The simulation results presented in this paper show that such a switch would induce quantitatively important reductions of matching grants. Citizens obviously take their spending decisions more consciously and consider the true costs of specific public spending projects. Given the evidence on the impact of direct democracy on spending and other economic 
policy outcomes reported by Feld and Kirchgässner (2000, 2001), the evidence presented in this paper additionally suggests that the introduction of a fiscal referendum is useful in order to restrict fiscal policies of representatives.

\section{Acknowledgements}

Helpful comments by Gebhard Kirchgässner, Friedrich Schneider and participants of the ECSPC-Conference on "Lobbying and Institutional Structure of Policy Making”, Università di Roma La Sapienza, September 2002 as well as financial support from the Swiss National Science Foundation (Project No. 5004-58524) are gratefully acknowledged.

\section{Notes}

1. Feld and Kirchgässner (2000) provide a survey on the fiscal impact of institutions of direct democracy.

2. Laws that affect public spending are subject to an optional legislative referendum in the canton of Vaud.

3. In some of these cantons, fiscal rcferendums were held in order to get citizens' permissions for the Swissair subsidies. Interestingly, many of these referendums failed to obtain citizens' support. Moreover, examples in Swiss history, like the textile industry in eastern Switzerland, in particular in St. Gallen, or the watch industry in Neuchâtel, exist that were unsuccessful in externalizing the costs of structural adjustments.

\section{References}

Anderson, G. M., \& Tollison R. D. (1991), Congressional influence and patterns of New Deal spending, 1933-1939. Journal of Law and Economics, 34, 161-175.

Becker, G. S. (1983), A theory of competition among pressure groups for political influence. Quarterly Journal of Economics, 98, 371-397.

Bernholz, P. (1995), Necessary and sufficient conditions of a viable democracy. In A. Breton, G. Galeotti, P. Salmon, \& R. Wintrobe (eds.), Understanding Democracy (pp 88-103). Cambridge, UK: Cambridge University Press.

Boehmke, F. J. (1999), The Initiative as a catalyst for policy change (mimeo). Pasadena: California Insititute of Technology.

Bohnet, I. \& B. S. Frey (1994), Direct-democratic rules: The role of discussion. Kyklos, 47, $341-354$

Borner, S., A. Brunetti, \& T. Straubhaar (1990), Schweiz AG: Vom Sonderfall zum Sanierungsfall? Zürich: NZZ.

Borner, S., A. Brunetti, \& T. Straubhaar (1994), Die Schweiz im Alleingang. Zürich: NZZ.

Cronin, Th. E. (1989), Direct democracy: The politics of initiative, referendum, and recall. Cambridge, MA: Harvard University Press.

Feld, L. P. \& G. Kirchgässner (2000), Direct democracy, political culture and the outcome of economic policy: A report on the Swiss experience. European Journal of Political Economy, 16, 287-306.

Feld, L. P. \& G. Kirchgässner (2001), The political economy of direct legislation: Direct democracy and local decision-making. Economic Policy, 33, 329-367. 
Feld, L. P. \& J. G. Matsusaka (2003), Budget referendums and government spending: Evidence from Swiss cantons. Journal of Public Economics, 87, 2703-2724.

Frey, B. S. \& A. Stutzer (2000), Happiness, economy and institutions. Economic Journal, 110, 918-938.

Gerber, E. R. (1999), The populist paradox: Interest group influence and the promise of direct legislation. Princeton, NJ: Princeton University Press.

Gramlich, E. (1977), Intergovernmental grants: A review of the empirical literature. In W. E. Oates (ed.), The Political Economy of Fiscal Federalism: Lexington. Lexington, KY, Books.

Grossman, P. J. (1990), The impact of federal and state grants on local government spending: A test of the Fiscal Illusion Hypothesis. Public Finance Quarterly, 18, 313 327.

Grossman, P. J. (1994), A political theory of intergovernmental grants. Public Choice, 78, 295-303.

Hamilton, A., J. Madison, \& J. Jay (1787/1788), The federalist papers (reprinted). New York: Bantam Books.

Heyndels, B., \& C. Smolders (1994), Fiscal illusion at the local level: Empirical evidence for the Flemish Municipalties. Public Choice, 80, 325-338.

Hines, J. R., \& R. H. Thaler (1995), Anomalies: The flypaper effect. Journal of Economic Perspectives, 9, 217-226.

Holsey, C. M. (1993), Price and income distortions under separate spending and taxing decisions. Journal of Public Economics, 50, 93-114.

Longchamp, C. (1991), Herausgeforderte demokratische Öffentlichkeit: Zu den Möglichkeiten und Grenzen des politischen Marketings bei Abstimmungen und Wahlen in der Schweiz. Schweizerisches Jahrbuch für Politische Wissenschaft, 31, 303-326.

Lowenstein, D. H. (1982), Campaign spending and ballot propositions: Recent experience, public choice theory, and the first amendment. University of California Law Review, 29, $505-641$.

Lutz, G. \& D. Strohmann (1998), Wahl- und Abstimmungsrecht in den Kantonen. Bern: Haupt.

Lydenberg, St. (1979), Bankrolling ballots: The role of business in financing state ballot question campaigns. New York: Council for Economic Priorities.

Matsusaka, J. G. (1995), Fiscal effects of the voter initiative: Evidence from the Last 30 years. Journal of Political Economy, 103, 587-623.

Niskanen, W. A. (1971), Bureaucracy and representative government. Chicago: Chicago University Press.

Oates, W. E. (1979), Lump-sum inter governmental grants have price effects. In P. Mieszkowski \& W. Oakland (eds.), Fiscal Federalism and Grants-in-aid. Washington, DC: Urban Institute.

Oates, W. E. (1999), An essay on fiscal federalism. Journal of Economic Literature, 37, 1120 1149.

Olson M. (1982), The rise and decline of nations: Economic growth, stagflation, and social rigidities. New Haven, CT: Yale University Press.

Pitlik, H., G. Schmid, \& H. Strotmann (2001), Bargaining power of smaller states in Germany's Länderfinanzausgleich 1979-1990. Public Choice, 109, 183-201.

Pommerehne, W. W. \& F. Schneider (1978), Fiscal illusion, political institutions, and local public spending. Kyklos, 31, 381-408.

Schaltegger, Ch. A. (2001), The effects of federalism and democracy on the size of government: Evidence from Swiss sub-national jurisdictions: ifo-studies, 47, 145-162.

Schneider, F. (1985), Der Einflu $\beta$ von Interessengruppen auf die Wirtschaftspolitik. Bern: Hampt. 
Schneider, F., H. Pitlik, \& H. Strotmann (2001), On the politicization of intergovernmental fiscal relations in Germany after unification. Working Paper No. 0105. Linz, Austria: University of Linz.

Shockley, J. S. (1985), Direct democracy, campaign finance and the courts: Can corruption, undue influence and declining voter confidence be found? University of Miami Law Review, $39,377-428$

Smith D. A. (1998), Tax crusaders and the politics of direct democracy, New York: Routledge.

Tovmo, P. \& T. Falch (2002), The flypaper effect and political strength. Economics of Governance, 3, 153-170.

Trechsel, A., \& U. Serdült (1999), Kaleidoskop Volksrechte: Die Institutionen der direkten Demokratie in den schweizerischen Kantonen (1970-1996), Basel: Helbing \& Lichtenhahn.

Wagner, R. E. (1991), Charging for government: User charges and earmarked taxes in principle and practice. London: Routledge.

Weingast, B.R., K. A. Shepsle \& Johnson, Ch. (1981), The political economy of benefits and costs: A neoclassical approach to distributive politics. Journal of Political Economy, 89, 642-664.

Wicksell, K. (1896), Finanztheoretische Untersuchungen nebst Darstellung und Kritik des Steuerwesens Schwedens. Jena: Gustav Fischer.

Winer, S. (1983), Some evidence on the effect of the separation of spending and taxing decisions. Journal of Political Economy, 91, 126-140.

Wyckoff, P.G. (1991), The elusive flypaper effect. Journal of Urban Economics, 30, 310-328.

Zisk, B. H. (1987), Money, media, and the grass roots: State ballot issues andthe election process. Newbury Park, CA: Sage. 